\title{
The African Charter on Democracy, Elections and Governance as a Justiciable Instrument
}

\author{
Ben Kioko* \\ African Court on Human and Peoples' Rights \\ ben_kioko@yahoo.com; Ben.Kioko@african-court.org
}

\begin{abstract}
The African Charter on Democracy, Elections and Governance requires state parties to establish and strengthen democratic institutions, the rule of law, human rights and independent electoral systems. However, the extent to which these provisions can be invoked by individuals and non-governmental organizations before a court of law is uncertain. It is also unclear whether such provisions guarantee "standalone" individual rights and as such whether the charter could be considered to be a human rights instrument. This article seeks to analyse whether the charter is a human rights instrument, as well as examining its justiciability in light of the decision of the African Court on Human and Peoples' Rights in APDH v Côte d'lvoire. The analysis highlights the court's decision affirming that the charter is a human rights instrument and that individuals and non-governmental organizations can file cases in a court of law seeking its enforcement.
\end{abstract}

\section{Keywords}

African Court on Human and Peoples' Rights, justiciability, human rights, democracy, elections, African Charter on Democracy, Elections and Governance

\section{INTRODUCTION}

In a landmark judgment of the African Court on Human and Peoples' Rights (ACtHPR) delivered on 18 November 2016, Côte d'Ivoire was ordered to amend its Law No 2014-335 of 18 June 2014 on its Independent Electoral Commission (IEC) to make it compliant with instruments to which it is a party. In the process, the ACtHPR considered whether the African Charter on Democracy, Elections and Governance (ACDEG) is a human rights instrument. It also considered whether the relevant Ivorian law providing for the composition, organization, duties and functioning of the IEC conforms with the ACDEG and Protocol A/SP1/12/01 on Democracy and Good Governance Supplementary to

Judge and vice president, African Court on Human and Peoples' Rights. Former legal counsel to the African Union Commission. The views expressed in this article are strictly personal to the author and are not binding on the court. 
the Protocol relating to the Mechanism for Conflict Prevention, Management, Resolution, Peacekeeping and Security (ECOWAS Democracy Protocol).

The Court also examined whether the failure by a state to put in place an independent and impartial electoral body violates the rights provided for in the African Charter on Human and Peoples' Rights (African Charter) and other relevant instruments ratified by the state concerned. Further, the ACtHPR discussed whether the existence of an imbalanced IEC violates the right to equality before the law and to equal protection from the law, as per articles 3 and 13(1) and (2) of the African Charter, articles 10(3) and 17(1) of the ACDEG, article 3 of the ECOWAS Democracy Protocol, article 1 of the Universal Declaration of Human Rights (UDHR) as well as article 26 of the International Covenant on Civil and Political Rights (ICCPR).

This article focuses on the justiciability of the ACDEG in light of the ACtHPR's decision. In other words, it deals with the question of whether the rights enshrined in the ACDEG can be litigated before the ACtHPR. To highlight the importance of the decision, the article first examines the background and unique attributes of the ACDEG, including key issues that emerged in the process of its adoption. This provides clarity on the primary objective of the charter from the perspective of the drafters and the contexts against which its provisions were formulated. It then analyses the ACtHPR's decision in Actions pour la Protection des Droits de l'Homme (APDH) $v$ Côte d'Ivoire to determine the justiciability of the ACDEG and its impact on the strengthening of democracy, good governance and the rule of law in Africa. In this context, the article highlights the extent to which the ACtHPR's judgment solidifies the justiciability of the provisions of the ACDEG and the challenges of translating the findings into reality. In particular, it elucidates the decision's regional normative standard-setting role concerning the nature of democratic institutions relating to elections and the promotion of the rule of law and human rights. The article concludes by highlighting the major findings of the previous sections.

\section{THE AFRICAN CHARTER ON DEMOCRACY, ELECTIONS AND GOVERNANCE}

\section{Overview}

The ACDEG was adopted on 30 January 2007 and entered into force on 15 February 2012. ${ }^{1}$ Its adoption was premised on the realization that conflicts on the continent were caused or exacerbated by many factors, notably including lack of democratic practices in the management of public affairs, nonobservance of human rights, as well as unfair electoral processes. ${ }^{2}$ The charter

1 On 16 January 2012, Cameroon became the 15th state to ratify the ACDEG and deposit the instrument of ratification.

2 See Declaration on the Principles Governing Democratic Elections in Africa, AHG/Decl.1 (XXXVIII), 2002, chap II: "(1) Democratic elections are the basis of the authority of any representative government. (2) Regular elections constitute a key element of the 
was seen as a bulwark to ensuring free, fair and credible elections, the building of democratic institutions and the rule of law, as well as deepening democratic ideals and values on the continent. ${ }^{3}$

The ACDEG is anchored in the Constitutive Act of the African Union (AU Constitutive Act), which commits African Union (AU) member states to participatory democracy, constitutionalism, rule of law, human rights, peace and security, good governance as well as sustainable human development in Africa. ${ }^{4}$ As of February 2019, the ACDEG had been signed by 46 member states and ratified and acceded to by 31, being 12 of the 15 member states in western Africa, six of the ten in southern Africa, eight of the 13 in eastern Africa, two of the nine in central Africa and three of the seven in northern Africa. It has been a slow process, which is not unusual for AU treaties. ${ }^{5}$

\section{Unique attributes of the ACDEG}

The ACDEG is regarded as a ground-breaking instrument in terms of the commitments member states have undertaken relating to good governance, participatory democracy, and principles and guidelines for the organization and management of public affairs in Africa, in particular the periodicity of credible and transparent elections managed by independent electoral bodies. ${ }^{6}$

The ACDEG reflects the shared values, standards and norms of the AU and its member states in the area of democracy and, together with the AU Constitutive Act, envisages that states will hold each other accountable to ensure compliance through the application of the sanctions provided for in article 23 of the AU Constitutive Act against states that fail to comply with the AU's principles and policies. ${ }^{7}$

The ACDEG was preceded by 18 instruments and frameworks, including the New Partnership for Africa's Development (NEPAD) and African Peer Review Mechanism. It incorporates these and other previous soft law instruments on democracy and governance ${ }^{8}$ into a single and consistent legally binding

contd

democratization process and therefore, are essential ingredients for good governance, the rule of law, the maintenance and promotion of peace, security, stability and development. (3) The holding of democratic elections is an important dimension in conflict prevention, management and resolution."

3 See ACDEG, preamble.

4 AU Constitutive Act, arts 3 and 4, adopted on 11 July 2000.

5 T Maluwa "Ratification of African Union treaties by member states: Law, policy and practice" (2012) 13/2 Melbourne Journal of International Law 636 at 639.

6 ACDEG, chap 7.

7 Id, art 23(2) states that "any Member State that fails to comply with the decisions and policies of the Union may be subjected to other sanctions, such as the denial of transport and communications links with other Member States, and other measures of a political and economic nature to be determined by the Assembly".

8 Declarations and decisions of the (O)AU, including: the 1990 Declaration on the Political and Socio-Economic Situation in Africa and the Fundamental Changes Taking Place in the World; the 1995 Cairo Agenda for the Re-launch of Africa's Economic and Social 
document. Another seven legal instruments were adopted after the ACDEG, making a total of $25 \mathrm{AU}$ instruments dealing with democracy and human rights. The charter is therefore largely a consolidation of commitments member states have already made, in various instruments, many of which are already being implemented.

The question that arises is whether the ACDEG is merely repetitive. A close review of its provisions leads one to conclude that it is not simply a duplication of previous similar instruments, but rather a unique instrument with commendable features that have great potential to promote and strengthen democracy, good governance and the rule of law in Africa.

Compared to other Organisation of African Unity (OAU) and AU instruments, the ACDEG is unique in at least six ways. First, the ACDEG is the first AU instrument that involves all the AU mechanisms in its implementation. ${ }^{9}$ Secondly, it has its own provisions regarding sanctions that complement the AU sanctions regime found in other instruments and could strengthen compliance with the AU's norms and values and promote accountability. In this regard, a breach of the ACDEG could invite sanctions in terms of article 46 of the charter itself, ${ }^{10}$ and articles 23(2) and $30^{11}$ of the AU Constitutive Act. Thirdly, article $8(2)$ of the ACDEG obligates state parties to "adopt legislative and administrative measures to guarantee the rights of women, ethnic minorities, migrants, people with disabilities, refugees and displaced persons and other marginalized and vulnerable social groups". ${ }^{12}$ This is the first AU instrument that seeks to address the challenges faced by "ethnic minorities, migrants, marginalized and vulnerable social groups". Fourthly, the charter is the most significant instrument on elections, in that it has 16 provisions relating to elections. Fifthly, uniquely, it is the only AU instrument that

contd

Development; the 1999 Algiers Declaration on Unconstitutional Changes of Government; the 2000 Lomé Declaration for an OAU Response to Unconstitutional Changes of Government; the 2002 (O)AU Declaration on Principles Governing Democratic Elections in Africa, decision EX.CL/Dec.31(III) adopted in Maputo, Mozambique, in July 2003. This last declaration was made in accordance with decision EX.CL/124(V), adopted in Addis Ababa, Ethiopia, in May 2004, that "requested the Commission to convene a meeting of Governmental Legal and other Experts to formulate a Draft Charter on Elections, Democracy and Governance in Africa, based on the collective commitments already made by Member States in these domains and submit the document thereof at its 7th Ordinary Session".

9 Notably, the AU Commission, the Pan-African Parliament, the Peace and Security Council, the ACtHPR, the African Commission on Human and Peoples' Rights, the Committee on the Rights and Welfare of the Child, the Economic, Social and Cultural Council and the regional economic communities (ACDEG, art 45(c)).

10 Art 46 provides that "the Assembly and the Peace and Security Council shall determine the appropriate measures to be imposed on any State Party that violates this Charter".

11 Art 30 stipulates that "Governments which shall come to power through unconstitutional means shall not be allowed to participate in the activities of the Union".

12 The ACDEG was adopted almost three years before the Kampala Convention on Internally Displaced Persons, 2009 (Kampala Convention). 
gives a legal basis, in its article 37, to the concepts of sustainable development and human security through the NEPAD objectives and the UN Millennium Development Goals. ${ }^{13}$ Sixthly, in terms of article 25(5) of the charter, "perpetrators of unconstitutional change of government may also be tried before the competent court of the Union", hence the insertion of this crime in the "International Crimes Protocol" for the ACtHPR, adopted in Malabo, Equatorial Guinea, on 27 June 2014. ${ }^{14}$ These provisions were included in response to the governance deficit on the continent and the challenge of the non-implementation of legal instruments by member states, by recommitting states in clearer language to deal with these issues in an instrument that has a sanctions regime and is justiciable.

Overall, the ACDEG provides a framework of norms and principles, the strict observance of which would significantly reduce the risk of unconstitutional changes of governments, popular uprisings and conflicts arising from competition for political power on the continent.

\section{Gaps in the ACDEG}

As comprehensive as the ACDEG is, there are gaps. For example, the drafters missed an opportunity to make a link between terrorism and governance, even though terrorism is to some extent caused and / or aggravated by the democratic deficits, marginalization, bad governance and lack of good electoral practices that the ACDEG seeks to address. ${ }^{15}$ There is also no indication of what a culture of democracy in articles 11, 12(2) and 29(2) means, and how or through what means this lofty objective will be achieved. If the intention was that this objective be achieved through, for example, "civic education in their educational curricula and develop[ment of] appropriate programmes and activities" (article 12(4)), this should have been clearly stated.

\section{Key issues and reservations in the ACDEG negotiation process}

In the process of negotiating the ACDEG, a number of key issues and reservations were raised by member states with regard to certain aspects of the draft charter, particularly those that states felt directly affected state sovereignty. ${ }^{16}$

13 Art 37 obligates state parties to "pursue sustainable development and human security through achievement of NEPAD objectives and the United Nations Millennium Development Goals".

14 Protocol on Amendments to the Protocol on the Statute of the African Court of Justice and Human Rights, 2014.

15 The issue of terrorism was neither raised in the initial drafts nor by the delegates, perhaps because it is adequately addressed in the 1999 AU Convention on Preventing and Combating Terrorism, which entered into force on 26 December 2002.

16 This section of the article is largely based on the author's personal observations and notes on the negotiating process, as well as official documents of the various meetings of senior officials, ministerial meetings and the session of the Assembly of Heads of State and Government at which the final text was formally considered and adopted. Also see Draft/Charter/II/Rev.1, Draft/Charter/II/Rev.2 and the report, Draft/Min/RPT/II of the 
Some member states were concerned about the concept of "democratic change of governments" contained in article 2(3), as it stood, which referred to promoting "the holding of regular free and fair elections to institutionalize legitimate authority of representative government as well as democratic change of governments" as read together with article $10(2) .{ }^{17}$ They felt that a regular change of government does not necessarily translate into democracy. Other states also expressed concerns about "political pluralism" in draft article 2(6), ${ }^{18}$ arguing that there was no evidence that democracy could only be assured through political pluralism. Questions were also raised about the meaning of "access to information, freedom of the press and accountability in the management of public affairs" in article 2(10). ${ }^{19}$

With regard to the issue of representative and democratically elected governments in article 3(4) (which as it stood stipulated the principle of organizing "regular, free and fair elections as the means for legitimate authority for a representative government"), ${ }^{20}$ the report of the meeting indicates that some delegations argued that "the representative nature of a government stemmed from democratic governance practices and therefore the concept of representative government should not be maintained in the text". ${ }^{21}$ Other delegations underscored "the need for any government, whether elected democratically or not, to incorporate peculiarities of national realities in order to be as representative as possible. These delegations called for maintaining the concept of representative government in the text". ${ }^{22}$ In the end, on that issue, the meeting "agreed on the need to promote a system of government which would be as representative and all-inclusive as possible" 23 and the formulation was changed to read: "[p]romotion of a system of government that is representative and all-inclusive". ${ }^{24}$

A number of states were further concerned about the import of draft article $8(2)^{25}$ and its possible contradiction with Islamic law and custom, particularly

contd

ministerial meeting on the ACDEG, 9-10 June 2006, Brazzaville, Congo (copies on file with the author).

17 The current art 10(2) provides: "States Parties shall ensure that the process of amendment or revision of their constitution reposes on national consensus, obtained if need be, through referendum."

18 Art 2(6) on objectives states, “... nurture, support and consolidate good governance by promoting democratic culture and practice, building and strengthening governance institutions and inculcating political pluralism and tolerance".

19 Art 2(10) was not amended and requires states to "foster citizen participation, transparency, access to information, freedom of the press and accountability in the management of public affairs".

20 See DraftMin/RPT/II, above at note 16, paras 21-23.

21 Id, para 22.

22 Ibid.

23 Id, para 23.

24 See conclusion, ibid.

25 Art 8(2) provides: "State Parties shall guarantee the rights of women, ethnic minorities, migrants, people with disabilities, refugees and displaced persons and other marginalized and vulnerable social groups." 
in so far as it requires state parties to "adopt legislative and administrative measures to guarantee the rights of women". They also enquired into the meaning of "other marginalized and vulnerable social groups". ${ }^{26}$

Draft article 10(2), as it stood, ${ }^{27}$ attracted a number of reservations during the negotiations. Several states considered the provision intrusive and prescriptive and wanted to understand whether a referendum would still be required if the existing constitution did not provide for one. In the end, the draft article was accepted with amendments. ${ }^{28}$

Draft article 19(1), (2) and (3) also attracted a number of questions and concerns in light of the fact that some states did not have "independent and impartial national electoral bodies (IEMBs) that shall manage electoral processes and systems". In some cases, these bodies reported to the minister in charge of the interior, who has overall responsibility in respect of elections. In at least one country, presidential elections are excluded from legal challenge in the judiciary ${ }^{29}$ although no state opposed the provision requiring the undertaking of state parties to establish and strengthen national mechanisms that redress election related disputes in a timely manner. With regard to paragraph (3), which initially required "fair and equitable access by contesting parties and candidates to the private and state-controlled media during elections", the scope was changed to "state-controlled media" to accommodate the concerns of some states that had argued that states could not legitimately exercise any or effective control over private media. ${ }^{30}$

The requirement in draft article 43(1) that states endeavour to provide "free and compulsory basic education to all, especially girls, rural inhabitants, minorities, people with disabilities and other marginalized social groups" attracted questions about its feasibility against the backdrop of limited resources. In the end, states accepted it as an aspirational provision.

At the June 2006 ministerial meeting in Brazzaville, with the view to finding a solution to the outstanding issues before the ordinary session of the Executive Council, discussions focussed on a number of issues, including "the independence of national electoral bodies, the repressive nature of democratically elected governments and revision of constitutions to prolong tenure of office". ${ }^{31}$ With regard to the notion of independence of the national

26 See Draft/Min/RPT/II, above at note 16. However, this aspect is from the author's personal notes and was not reflected in the brief report of the meeting.

27 Art $10(2)$ as it stood provided that: "State Parties shall ensure that a referendum is entrenched as one of the best means of amending the constitution."

28 For the final version of art 10(2), see above at note 17.

29 Tanzania's current Constitution of 1977 , as amended, establishes a specialized electoral court to deal with all electoral disputes arising out of parliamentary and other elections, except for presidential elections.

30 See Draft/Min/RPT/II, above at note 16. However, this aspect is from the author's personal notes and was not reflected in the brief report of the meeting.

31 See id, para 16. 
electoral bodies (the current article 17), ${ }^{32}$ it was asserted that "the organization of elections was the responsibility of the state and that under such circumstances, the issue was rather one of impartiality and neutrality" 33 and "emphasized that the independence of national electoral bodies could only be in the operational sense, that is, with regard to decision-making and not necessarily in terms of structure and resources". ${ }^{34}$ In the end, the meeting agreed that "the principle of independence of national electoral bodies should be adopted on the understanding that such independence was operational". ${ }^{35}$ However, this understanding was not reflected in the adopted ACDEG and the AU Commission issued no official travail preparatoire. In the circumstances, in APDH $v$ Côte d'Ivoire the ACtHPR limited its consideration of the ACDEG to its provisions and held that "an electoral body is independent where it has administrative and financial autonomy; and offers sufficient guarantees of its members' independence and impartiality". ${ }^{36}$

In all the various meetings, including in Brazzaville, draft article 25(5) (the present article 23(5)), which originally prohibited constitutional amendments to extend the tenure of a government in power, was the most controversial and remained unresolved until the Executive Council's very last session. Discussions on this paragraph ${ }^{37}$ focused particularly on whether or not to maintain the whole paragraph and the phrase "to prolong the tenure of office for the incumbent government". Three delegations were against maintaining this phrase on the grounds that such a prolongation "depended on the expression of democracy by the people, in accordance with the constitutional rules and procedures in force". ${ }^{38}$ Other delegations insisted on the need to maintain this phrase, basing their argument on the fact that "it was essential to ensure democratic alternation and thus prevent any attempt to remain indefinitely in power through revision of constitutions and relevant legal instruments by the incumbent government, contrary to the spirit and letter of constitutional provisions". ${ }^{39}$

32 Id, paras $17-20$.

33 Id, para 17.

34 Id, para 19.

35 Id, para 20.

36 APDH $v$ Côte d'Ivoire app no 003/2017, judgment of 18 November 2016, para 118.

37 Id, paras 24-26. Art 25(5) of the draft Brazzaville text read: "Amendment or revision of constitutions and legal instruments, contrary to the provisions of the constitution of the State Party concerned, to prolong the tenure of office for the incumbent government ...". The final provision is now contained in art 23(5) of the ACDEG, which speaks to: "any amendment or revision of the constitution or legal instruments, which is an infringement on the principles of democratic change of government".

38 See Draft/Min/RPT/II, above at note 16, para 25.

39 Id, para 27. "For want of a consensus on the provisions of paragraph 5 of art 25, the Ministers decided to refer the matter for a final decision to the Executive Council and the Assembly of Heads of State and Government scheduled to hold from 25 June to 2 July 2006": id, para 27. At the ninth ordinary session of the Executive Council held on 25 June 2006 in Banjul, The Gambia, the AU Commission was requested "to review the legal form of the Draft Charter including the content of article 25(5) in the light 
At the Executive Council session held in Addis Ababa, Ethiopia, in January 2007, at which the draft text was considered and subsequently approved, the issue of the revision of constitutions and legal instruments to prolong tenure of office (article 25(5)) arose again, this time raised by Algeria and supported by Uganda. However, after consultation, an understanding was arrived at and consensus reached to approve the entire draft ACDEG unanimously and to recommend it to the Assembly of Heads of State and Government for adoption. ${ }^{40}$ As such, the Executive Council adopted decision EX.CL/Dec.320 (X), which:

"(2) Reiterates the importance of the African Charter on Democracy, Elections and Governance in the consolidation of commitments collectively taken by member states to promote Democracy and Good Governance on the Continent; (3) Takes Note of the clarifications provided by the Legal Counsel of the Commission on the concerns raised by some member states; and Recommends the Charter, which is a major step towards the realization of the democratic agenda of the Union, for adoption by the Assembly".

While the experts and ministers appreciated the importance of the ACDEG (as indicated in the Executive Council decision), they had no direct discussions on the issue of the ACDEG's justiciability. Nevertheless, delegates approved the provision in the current article 25(5), which provides that "[p]erpetrators of unconstitutional change of government may also be tried before the competent court of the Union", suggesting that some of them may have had in mind the possibility of at least some of the provisions of the charter being justiciable.

\section{THE CHANGING NATURE OF THE NOTION OF JUSTICIABILITY UNDER INTERNATIONAL HUMAN RIGHTS LAW}

The question of justiciability, broadly understood as "justiciable or the quality or state of being appropriate or suitable for adjudication by a

contd

of comments and observations made on that article and resubmit it to the next session ... for its consideration and approval": decision EX.CL/Dec.288 (IX).

40 The consultation that resulted in a breakthrough was held outside the AU Conference Centre and involved two ministers, one opposed to the provision and the other defending the current formulation. It was facilitated by the author, who was then legal counsel. The main concern, as articulated by the first minister, was that his country intended within a few months to amend the constitution to extend the government's tenure of office and, in his view, it was not clear from the provision that this could be done. The other minister explained, supported by the legal counsel, that such action was not prohibited so long as it was done in accordance with the constitution. As a way out, it was agreed that the country concerned would ask the legal counsel at the plenary for an explanation of the meaning of art 25(5). Subsequently, the concerned country would formally request the legal counsel in writing to reiterate his explanation to the plenary. This was done, which explains why para 3 of Executive Council decision EX. $\mathrm{CL} /$ Dec.320 (X) refers to clarifications provided by legal counsel. 
court",41 has long bedevilled both domestic and international courts. Justiciability has a critical place in the competence of courts to entertain a particular matter, more so because of the absence of a clear demarcation between those matters that are considered justiciable and those considered nonjusticiable. Furthermore, questions of justiciability are often seen to raise other issues regarding separation of powers, political processes / democracy, the role of courts at the domestic level, and perhaps also the appropriateness of the degree of scrutiny at international level as a matter of subsidiarity. This explains why justiciability, in one way or another, recurrently appears as an issue that international courts have to tackle, implicitly or explicitly, as an essential prerequisite for adjudication. ${ }^{42}$

Once a case contains non-justiciable issues, courts generally refuse to take cognizance of or decide on such issues, either on account of their nature or in order to avoid encroaching upon executive or legislative powers. ${ }^{43}$ In domestic systems, matters that are purely political, religious, ideological or administrative are often considered to be beyond the reach of judicial assessment and thus non-justiciable. These issues are regarded as matters "not amenable to resolution through judicial processes". ${ }^{44}$ In APDH $v$ Côte d'Ivoire, the ACtHPR, too, had to address this matter by determining whether the application filed before it, although possibly of a political nature, involved the violation of human rights

In international law, the concept of justiciability is a well-recognized doctrine as well as a primary consideration of regional and international judicial institutions. In the jurisprudence of international tribunals, a non-justiciable matter is considered to be one that is "not capable of solution by the application of a rule of law", not belonging to one of those questions that "no country could safely submit to arbitration" and that "does not have its origin in an objectively justified demand for a change of the existing law". ${ }^{45}$ Despite the fact that the concept of justiciability is still an indispensable prerequisite for courts to consider a particular matter, its scope of application has evolved over time.

The notion of justiciability takes a different, somehow additional, shape in international human rights law, where some rights (mainly economic, social and cultural) were considered unenforceable (non-justiciable) before national and international courts, ${ }^{46}$ as their enforcement requires resources

41 See the definition of "justiciability" in HC Black Black's Law Dictionary (1979, West Publishing) at 943.

42 H Rohde and D Spaeth Supreme Court Decision Making (1976, Freeman) at 156.

43 Ibid.

44 Ibid.

45 H Lauterpacht "The doctrine of non-justiciable disputes in international law" (1928) 24 Economica 277 at 289.

46 D Stewart and M Dennis "Justiciability of economic, social and cultural rights: Should there be an international complaints mechanism to adjudicate the rights to food, water, housing and health?” (2004) 98/3 American Journal of International Law 462. 
and capacity that are scarce among states, thus resulting in progressive realization. ${ }^{47}$

The development of international human rights with a set of ever burgeoning entitlements in the political, social and economic arena of individuals has blurred the boundary between justiciable and non-justiciable matters. A close review of the jurisprudence of international and regional judicial and quasijudicial institutions suggests a shift from judicial acquiescence to an inquisitive and balancing approach towards justiciability, especially when human rights issues are implicated. ${ }^{48}$

The Court's decision in APDH $v$ Côte d'Ivoire should be seen in the light of this trend. Although the ACDEG contains many matters that would normally be considered "purely political", this did not prevent the ACtHPR from applying the charter in this case. ${ }^{49}$

\section{THE CHARTER AS A JUSTICIABLE INSTRUMENT: APDH $V$ CÔTE D'IVOIRE}

\section{Facts of the case}

On 28 May 2014 the National Assembly of Côte d'Ivoire adopted Law No 2014-335, relating to the IEC. Two days later, Kramo Kouassi, acting on behalf of a group of 29 parliamentarians, seized the Constitutional Council of Côte d'Ivoire with a petition to declare four provisions of this law unconstitutional. Kouassi argued that these provisions contravened article 2 and article 33 of the Ivorian Constitution, which guarantee the right to equality before the law, and free, fair and universal suffrage, respectively. ${ }^{50}$

47 International Covenant on Economic, Social and Cultural Rights (adopted on 16 December 1966), art 2(1).

48 In recent years, economic, social and cultural rights previously considered "nonjusticiable" have been litigated in different international and regional judicial and quasijudicial institutions. See Purohit and Moore $v$ Gambia comm 241/2000, decided at the 33rd ordinary session of the African Commission on Human and Peoples' Rights (ACHPR), 1529 May 2003 (dealing with the right to health of mental health patients); SERAC and CESR $v$ Nigeria ACHPR case no 155/96, decision made at 30th ordinary session, Banjul, The Gambia, 13-27 October 2001 (dealing with the right to health and the implied rights to food and housing); Comunidad Mayagna (Sumo) Awas Tingni $v$ Nicaragua Inter-American Court of Human Rights Series C, no 79, 31 August 2001 (involving the right to property); and FIDH $v$ France complaint no 14/2003, 8 September 2004 (dealing with the right to medical assistance of non-nationals). The Optional Protocol to the International Covenant on Economic, Social and Cultural Rights enables victims of economic, social and cultural rights violations to seek justice at the international level, when unable to do so in their own countries.

49 For a more detailed discussion of APDH $v$ Côte d'Ivoire, please see G Niyungeko "The African Charter on Democracy, Elections and Governance as a human rights instrument" in this issue.

50 These assertions were contained in his application before the ACtHPR and were not contested by the respondent state. 
In his petition to the council, Mr Kouassi argued that representation in the IEC was imbalanced, as the law allows a personal representative of the president of the republic and the president of the National Assembly to have membership in the IEC. He also added that representation in the IEC of the minister in charge of economy and finance, the High Judicial Council, the regional prefect, the department prefect and the sub-prefect is superfluous, in the sense that the same law provides that they shall be accorded government assistance in terms of administrative, financial and technical staff. On this basis, he alleged that the composition of IEC was unfair and violated the right to equality as it created, in favour of the president of the republic, unequal treatment on account of the over-representation of the president within the IEC.

After reviewing his petition, the Constitutional Council dismissed $\mathrm{Mr}$ Kouassi's prayers on 12 July 2014 and declared the provisions of the impugned law to be in conformity with the constitution. Following this decision, APDH (an Ivorian non-governmental human rights organization) seized the ACtHPR with the instant case, alleging that Côte d'Ivoire had, by adopting Law No 2014-335, especially its articles 5, 15, 16 and 17, violated its commitment to establish an independent electoral body as well as its commitment to protect the right to equality before the law and to equal protection by the law, as prescribed in articles 3 and 13(1) and (2) of the African Charter, articles 10(3) and 17(1) of the ACDEG, article 3 of the ECOWAS Democracy Protocol, ${ }^{51}$ article 7 of the UDHR and article 26 of the ICCPR. ${ }^{52}$

The applicant also implored the ACtHPR to order Côte d'Ivoire to review the law in light of its international commitments and to make its electoral body compliant with the provisions of the ACDEG. For its part, the respondent state prayed the ACtHPR to declare the application inadmissible for failure to exhaust local remedies and, if the court declared the application admissible, to rule that it was not founded in law and consequently dismiss it. ${ }^{53}$

In order to make a proper determination of the issues, pursuant to rule 45 (2) of its rules and paragraph 45 of its practice directions, the ACtHPR solicited the opinion of the AU Commission and the African Institute of International Law on the question of whether the ACDEG is a human rights instrument within the meaning of article 3 of the Protocol to the African Charter on Human and Peoples' Rights on the Establishment of the African Court on Human and Peoples' Rights (1998) (the Court Protocol). The two organizations submitted their opinions on 29 October 2015 and 7 January 2016, respectively.

51 Art 3 states: "The bodies responsible for organising the elections shall be independent or neutral and shall have the confidence of all the political actors. Where necessary, appropriate national consultations shall be organised to determine the nature and the structure of the bodies."

52 ICCPR, art 26 provides: "All persons are equal before the law and are entitled without any discrimination to the equal protection of the law."

53 See APDH $v$ Côte d'Ivoire, above at note 36, paras 37-40. 


\section{Analysis}

\section{Jurisdiction and admissibility}

Following the usual processes that a new application undergoes from filing to finalization, the ACtHPR noted that none of the four limbs of its jurisdiction was in contention between the parties and that nothing in the pleadings indicated that the court did not have jurisdiction. Accordingly, the ACtHPR examined each limb of its jurisdiction and made the following findings.

On its material jurisdiction, the ACtHPR noted in accordance with article 3(1) of the Court Protocol ${ }^{54}$ that its subject matter jurisdiction extends to all cases and disputes involving the interpretation of provisions of the African Charter and other human rights instruments ratified by Côte d'Ivoire. Given that APDH invoked the provisions of the African Charter, the ACDEG and the ECOWAS Democracy Protocol, the court held that it had material jurisdiction to interpret and apply them. ${ }^{55}$

After taking cognizance of the fact that Côte d'Ivoire was a state party to the African Charter as well as the Court Protocol and had deposited the declaration required under articles 5(4) and 34(6) of the protocol, ${ }^{56}$ the status of the applicant, and when and where the facts of the case took place, the ACtHPR found that it had personal, ${ }^{57}$ temporal and territorial jurisdiction ${ }^{58}$ over the application.

\section{Admissibility conditions}

In its established jurisprudence, the ACtHPR usually relies on rule 40 of its rules, article 56 of the African Charter and article 6 of the Court Protocol ${ }^{59}$ to decide on the admissibility of an application. Rule 40 provides seven admissibility requirements. ${ }^{60}$ The respondent had challenged only two requirements, relating to the language used by the applicant and the exhaustion of local remedies, which the ACtHPR dealt with at length, having satisfied itself that the other uncontested requirements had been met. ${ }^{61}$

54 Art 3(1) extends the ACtHPR's jurisdiction "to all cases and disputes submitted to it concerning the interpretation and application of the Charter, this Protocol and any other relevant human rights instrument ratified by the States concerned".

55 See APDH $v$ Côte d'Ivoire, above at note 36, para 65.

56 Arts 5(3) and 34(6) limit access to the ACtHPR by non-governmental organizations and individuals to cases against states that have filed a declaration "accepting the competence of the Court to receive cases" from individuals and NGOs.

57 See APDH $v$ Côte d'Ivoire, above at note 36, paras 43-46.

58 Id, para 67.

59 Nobert Zongo and Others $v$ Burkina Faso appln no 013/2011, judgment of 28 March 2014, para 68. Reverend Christopher R Mtikila $v$ Tanzania appln no 011/2011, judgment of 14 June 2013, para 82.1.

60 Paras (3) and (5) contain two conditions relevant to this case, providing respectively that: applications do "not contain any disparaging or insulting language" and are "filed after exhausting local remedies, if any, unless it is obvious that this procedure is unduly prolonged".

61 See APDH $v$ Côte d'Ivoire, above at note 36, paras 73-75. 
With regard to the allegation that the language used in the application was insulting towards the state and its institutions, the ACtHPR dismissed the objection for lack of evidence showing that the expressions used by the applicant were disparaging or insulting.

In this regard, the ACtHPR cited the decision of the African Commission on Human and Peoples' Rights (ACHPR) in Zimbabwe Lawyers for Human Rights \& Associated Newspapers of Zimbabwe $v$ Zimbabwe ${ }^{62}$ and held that nothing in the pleadings submitted before it suggested that any "remark or language ... is used in [in the application] in a manner calculated to pollute the minds of the public or any reasonable man to cast aspersions on and weaken public confidence". ${ }^{63}$

The Court's endorsement of the ACHPR's test that an application is inadmissible if the language "is calculated to pollute the minds of the public or any reasonable man to cast aspersions on and weaken public confidence" gives rise to a host of questions. Commenting on this test, Windridge asked exactly what is "polluting the minds" of the public and what kind of statements are capable of achieving this. He also pointed out the difficulty of understanding what "casting aspersions" means and on whom. With regard to "weakening public confidence", he queried the object of the weakening confidence "in what, or on whom". ${ }^{64}$ In Windridge's opinion, this test suggests that an application could be declared inadmissible and struck off because, although entirely factual, some statements used in it cast the respondent state in a negative light, resulting in a situation where an application containing statements that are not slanderous and false is struck out simply because the ACtHPR decides that it "weakens public confidence". ${ }^{65}$ These are no doubt pertinent observations that the ACtHPR may, perhaps, wish to address and clarify further, whenever an opportunity arises in the future.

On the issue of the exhaustion of local remedies, the ACtHPR referred to its previous jurisprudence, where it had identified three cumulative conditions that must be met: availability, effectiveness and sufficiency of the remedies. ${ }^{66}$ The Court noted that the impugned law did not relate to public freedoms and, for that reason, the applicant could not refer it to the Constitutional Council for determination. ${ }^{67}$ It was also clear to the ACtHPR that the Constitutional Council of the state of Côte d'Ivoire had already ruled on the constitutionality

62 Comm no 284/2003, ACHPR (3 April 2009), para 9. The Court had adopted the same reasoning in Nobert Zongo, above at note 59, para 68 and Matter of Reverend Christopher Mtikila, above at note 59 .

63 APDH $v$ Côte d'Ivoire, above at note 36, paras 73-75.

64 O Windridge "Equality and electoral commissions: APDH v Côte d'Ivoire" (7 February 2017) The ACtHPR Monitor, available at: <http://www.acthprmonitor.org/equality-and-electoralcommissions-apdh-v-the-republic-of-cote-divoire/> (last accessed 12 December 2018).

65 Ibid.

66 See APDH $v$ Côte d'Ivoire, above at note 36, paras 93-95.

67 Art 77(2) provides: "human rights advocacy associations may refer to the Constitutional Council only laws relating to public freedoms". 
of the impugned law, holding that those provisions were in conformity with the constitution. On this basis, the ACtHPR found that it was not necessary for the applicant to exercise the remedies mentioned by the respondent, as "there was no need to go through the same judicial process the outcome of which was known". ${ }^{68}$ Consequently the court declared the application admissible.

\section{Merits}

On the merits, the ACtHPR dwelt on two allegations, namely that the respondent state had violated its obligation to establish an independent and impartial electoral body and had violated its obligation to protect the right to equality before the law and equal protection by the law.

The allegation that the respondent state violated its obligation to establish an independent and impartial electoral body: The applicant submitted that the right for Ivorian citizens to have an independent and impartial electoral body emanates from the commitments made by Côte d'Ivoire under article 17 of the ACDEG. ${ }^{69}$ The applicant contended that the majority of the members of the Ivorian electoral body, the IEC, represented groups, personalities and political parties with special interests to protect and, hence, could not claim to be independent or impartial, since an agent cannot be independent from his principal. The respondent denied this, claiming that the composition of the IEC integrated all parties concerned for the proper conduct, transparency and credibility of the electoral exercise. It also maintained that the IEC's configuration had been arrived at consensually. The state further argued that the members of the electoral commission were not subject to any administrative hierarchy and did not receive instructions from the government.

The Court held that an electoral body is independent when it has administrative and financial autonomy, and offers sufficient guarantees of its members' independence and impartiality. ${ }^{70}$ The Court observed that the issue at hand was to establish whether the IEC's composition was balanced. On this point, it noted that, although article 1(2) of the impugned law provided that the IEC was an "independent administrative authority endowed with legal personality and financial autonomy", institutional independence is not enough to guarantee transparent, free and fair elections as envisaged in the ACDEG

68 In conformity with its previous decision in Lohe Issa Konate $v$ Burkina Faso appln 004/2013, judgment of 5 December 2014, para 112.

69 Art 17 obligates state parties to: “(1) Establish and strengthen independent and impartial national electoral bodies responsible for the management of elections. (2) Establish and strengthen national mechanisms that redress election-related disputes in a timely manner. (3) Ensure fair and equitable access by contesting parties and candidates to state controlled media during elections (4) Ensure that there is a binding code of conduct ... The code shall include a commitment by political stakeholders to accept the results of the election or challenge them in through exclusively legal channels."

See APDH $v$ Côte d'Ivoire, above at note 36, paras 121-30. 
and the ECOWAS Democracy Protocol. ${ }^{71}$ The electoral body should accordingly be legally constituted in a way that guarantees independence and impartiality and should be perceived as such. The Court noted that the IEC did not have a balanced composition, with the government of the respondent state holding eight seats, and other political groups and civil society holding just four. This imbalance was reinforced by the IEC's voting structure, with decisions made by a simple majority. ${ }^{72}$

The Court consequently held that, by adopting the impugned law, the respondent state violated its commitment to establish an independent and impartial electoral body as provided under article 17 of the ACDEG. The Court further held that the violation of this article affected the right of every Ivorian citizen to participate freely in the conduct of public affairs of his country, as guaranteed by article 13 of the African Charter.

The allegation that the respondent state has violated its obligation to protect the right to equality before the law and equal protection by the law: On this second allegation, the applicant argued that the impugned law accorded advantages to certain candidates at the expense of others, that the president of the republic was over-represented (while independent candidates and those of the opposition were not fairly represented) and that during elections the members could tilt the balance in favour of the president. Consequently, the applicant averred that the respondent state violated its obligation to protect the right to equality before the law and to equal protection by the law, as enshrined in several international human rights instruments to which the respondent is a party. ${ }^{73}$

The respondent state refuted the claim, contending that the allegation challenged the strong presence in the IEC of members appointed by political parties or the political authorities and that the impugned law did not deprive Ivorian citizens who have fulfilled the requisite conditions of the right to participate in the public affairs of their country.

The Court noted that equality and non-discrimination are fundamental principles of international human rights law and that everyone, without discrimination, should enjoy all the rights. ${ }^{74}$ Article $10(3)$ of the ACDEG, ${ }^{75}$ article

71 Id, para 123.

72 This imbalance was also highlighted in the October 2015 report of the AU Elections Observer Mission on the 2015 elections in Côte d'Ivoire, which noted (APDH $v$ Côte d'Ivoire, para 132) "that there is an imbalance in the numerical representation of the ruling coalition and the political parties" and that "the electoral authority does not command consensus within the political class, although the current IEC is the outcome of negotiations between the ruling party and the opposition parties, despite its heavy political component".

73 See APDH $v$ Côte d'Ivoire, above at note 36, paras 137-39.

74 Id, para 142.

75 ACDEG, art 10(3) stipulates: "State Parties shall protect the right to equality before the law and equal protection by the law as a fundamental precondition for a just and democratic society." 
3 of the African Charter ${ }^{76}$ and article 26 of the ICCPR, ${ }^{77}$ on which the applicant relied, all prescribe that everyone is equal before the law and that the principle of equality presupposes that the law protects everyone without discrimination. ${ }^{78}$ The Court further noted that the European Court of Human Rights had adopted a similar approach in the matter of Yumak Sadak $v$ Turkey, where it declared that "with regard to electoral systems, the ACtHPR's task is to determine whether the effect of the rules governing parliamentary elections is to exclude some persons or groups of persons from participating in the political life of the country; and whether the discrepancies created by a particular electoral system can be considered arbitrary or abusive or whether the system tends to favour one political party or candidate by giving them an electoral advantage at the expense of others". ${ }^{79}$

In the end, the ACtHPR found that the composition of the IEC was imbalanced in favour of the government and that this imbalance affected its independence and impartiality. Furthermore, the impugned law gave the president of the republic an "incumbent advantage" by placing him or any other candidate from his party in a much more favourable situation in relation to the other candidates. The Court therefore held that, by not placing all the potential candidates on the same footing, the law violated the right to equal protection of the law as enshrined in the human rights instruments ratified by the respondent state, especially article 10(3) of the ACDEG and article 3 of the African Charter.

\section{THE PECULIAR FEATURES AND CONTRIBUTIONS OF THE JUDGMENT}

Close scrutiny of the APDH $v$ Côte d'Ivoire judgment shows that the decision contains five major components or peculiar features, some of which may be cited as examples of positive contributions to international human rights jurisprudence. This article now seeks to outline and comment on these distinct features or major components of the judgment.

\section{Broad subject matter jurisdiction}

One of the salient features of the ACtHPR's judgment in APDH $v$ Côte d'Ivoire is its affirmation of the broad subject matter jurisdiction of the court. As

76 The African Charter, art 3 provides: "(1) Every individual shall be equal before the law. (2) Every individual shall be entitled to equal protection of the law."

77 ICCPR, art 26 provides: "All persons are equal before the law and are entitled without any discrimination to the equal protection of the law. In this respect, the law shall prohibit any discrimination and guarantee to all persons equal and effective protection against discrimination on any ground such as race, colour, sex, language, religion, political or other opinion, national or social origin, property, birth or other status."

78 J Andriantsimbazovina, H Gaudin, J-P Maguénaud, S Rials and F Sudre (eds) Dictionary of Human Rights (2008, French University Press) at 284. See also J Salmon (ed) Dictionnaire de Droit International Public [Dictionary of International Public Law] (2001, Bruylant) at 344, as quoted in APDH $v$ Côte d'Ivoire, above at note 36, paras 146-47.

Appln 1022/03, judgment of 8 July 2008, para 21. 
indicated above, article 3 of the Court Protocol extends the court's jurisdiction to all cases and disputes submitted to it concerning the interpretation and application of the African Charter, the Court Protocol and any other relevant human rights instrument ratified by the states concerned.

This provision gives the ACtHPR the mandate to invoke not only those human rights treaties concluded under the auspices of the AU, but also other bilateral and multilateral conventions at regional and international level to which a state may be a party. This is very important, because it would allow the ACtHPR to rectify normative ambiguities and gaps that exist within the African human rights charter system.

It is worth noting that the jurisdiction granted to the ACtHPR under article 3(1) of the Court Protocol is wider than that of the ACHPR. Although the ACHPR is required to draw inspiration from various international law instruments, ${ }^{80}$ according to Viljoen, "its main role is to ensure observance of the African Human Rights Charter. In contrast, the ACtHPR is entitled not only to use the instruments as interpretative guides but also to apply them to states that are parties" ${ }^{81}$ This has the positive consequence of enlarging the legal basis of human rights protection within the African region. ${ }^{82}$

It should however be appreciated that, despite the fact that article 3 of the protocol grants a broad subject matter jurisdiction to the ACtHPR in contentious cases by allowing it to resolve disputes arising from, theoretically, all other human rights instruments, there are certain limits to the extension in the qualifications "relevant", "ratified", "human rights" and "the state concerned". These qualifications exclude the possibility that the court may interpret or apply non-binding declarations or treaties that may not fall within the ambit of "human rights instruments". In addition, the ACtHPR may not refer to treaties that the state party to the proceedings has not ratified.

\section{The Charter as a human rights instrument}

In APDH $v$ Côte d'Ivoire, the ACtHPR also had to consider whether the ACDEG is a human rights instrument in order to establish its jurisdiction. In the ACtHPR's opinion, "in determining whether a convention is a human rights instrument, it is necessary to refer in particular to the purposes of such Convention [as] reflected either by an express enunciation of the subjective rights of individuals or groups of individuals, or by a prescription mandatory on states parties for the consequent enjoyment of the said rights". ${ }^{83}$

80 The African Charter, arts 60 and 61.

81 F Viljoen International Human Rights Law in Africa (2007, Oxford University Press) at 444.

82 The ACtHPR may also use this provision in the future to apply instruments including: the AU Convention on Preventing and Combating Corruption, 2003; the Kampala Convention; the Protocol to the African Charter on Human and Peoples' Rights on the Rights of Older Persons, 2016; and the AU Convention on Cyber Security and Personal Data Protection, 2014.

83 APDH $v$ Côte d'Ivoire, above at note 36, para 57. 
Given that the African Charter (under article 13) and the ICCPR (under article 26) to which the respondent is a party contain provisions directly conferring the rights allegedly violated, and that state parties to the ACDEG as well as to the ECOWAS Democracy Protocol are obliged to establish independent and impartial national electoral organs and facilitate the exercise and enjoyment of the rights enshrined under those articles, the ACtHPR held that the ACDEG and ECOWAS Democracy Protocol are human rights instruments. ${ }^{84}$ Although the latter instruments do not provide a list of rights and freedoms, the ACtHPR nevertheless considered them to be "human rights instruments" for they provide the mechanism to realize the enjoyment of rights and freedoms enshrined in other instruments, notably the African Charter and the ICCPR. The Court therefore addressed the matter by establishing a nexus between specific rights in the African Charter and relevant provisions in the ACDEG, in relation to the rights the applicant alleged had been violated, including the right to participation and equal protection before the law. ${ }^{85}$

\section{The Court as a "regional constitutional court"}

The other intriguing aspect of the ACtHPR's decision in APDH $v$ Côte d'Ivoire lies in its order requiring the respondent to amend its domestic legislation. After having found that the respondent had violated articles 10(3) and 17 of the ACDEG, article 3 of the ECOWAS Democracy Protocol, articles 3(2) and 13(1) and (2) of the African Charter, as well as article 26 of the ICCPR, the ACtHPR ordered Côte d'Ivoire to amend its electoral Law No 2014-335 of 18 June 2014 to "make it compliant with" these instruments. ${ }^{86}$

In comparison to other similar regional and international human rights bodies, this is a very bold and proactive approach. Its European counterpart, for example, has rarely held a state responsible for the violation of human rights when it comes to electoral laws or demanded a state found to have violated human rights to amend its law. In Yumak and SADK $v$ Turkey, to which the ACtHPR itself made reference, ${ }^{87}$ the European Court of Human Rights (European Court) neither found a violation of article 3 of Protocol 1 to the European Convention on Human Rights, nor ordered Turkey to amend its electoral legislation. ${ }^{88}$ This was despite the fact that the European Court found that the minimum threshold of votes that a party should obtain in elections to achieve representation in Parliament needed "to be lowered and / or for corrective counterbalances to be introduced to ensure optimal representation of the various political tendencies" ${ }^{89}$ In view of the extreme diversity of

\footnotetext{
84 Id, paras 57-66.

85 Id, paras 143 and 144. For the text of ACDEG, art 10(3), see above at note 75 . For art 3 of the African Charter, see above at note 76.

86 APDH $v$ Côte d'Ivoire, above at note 36, para 153.

87 Id, para 148.

88 Yumak and SADK, above at note 79.

89 Id, para 77.
} 
electoral systems adopted by states, the European Court was of the opinion that the manner in which a state sets up its electoral system falls within the margin of appreciation of the domestic authorities "who are best placed to assess the choice of an appropriate electoral system". 90

In APDH $v$ Côte d'Ivoire, the ACtHPR did not adopt a similar consideration of giving some latitude to the respondent in designing its electoral commission. The Court simply assessed whether the manner in which the IEC was composed passed muster with standards of independence and impartiality and, when it found that it did not, ordered the respondent to amend its law. By doing so, the ACtHPR appears to be acting and establishing itself as a "regional constitutional court" with the authority not only to declare the incompatibility of particular domestic legislation with international human rights law, but also explicitly to order its amendment.

This is not the first time that the ACtHPR showed no hesitation in ordering states to amend their domestic laws where it found violations of human rights as a result of the application of those laws. In its previous jurisprudence in the matters of Lohe Issa Konate $v$ Burkina Faso and Rev Christopher R Mtikila v United Republic of Tanzania, the ACtHPR directed Burkina Faso and Tanzania to amend their national defamation and electoral laws (including constitutional provisions), respectively, to make them congruent with international human rights standards. ${ }^{91}$ The court's decision in APDH $v$ Côte d'Ivoire is thus an extension or continuation of the same trend.

Considering that the ACtHPR is a regional human rights court with competence limited to human rights issues, one may anticipate that its current tendency of acting as a sort of "regional constitutional court" may draw criticism and even a possible backlash from states. ${ }^{92}$ By definition, a constitutional court deals primarily with constitutional law, with its main authority being to rule on whether laws that are challenged are in fact unconstitutional, in other words whether they conflict with constitutionally established rules, rights and freedoms, and it has the power to strike out laws that are not compliant. In contrast, a human rights court determines whether there have been violations of human rights and orders reparations, and in a few cases may order provisional measures. Intuitively, the ACtHPR's forthright approach in dealing with especially politically sensitive matters that directly affect state sovereignty, such as elections and electoral laws, could be met with resistance from states, considering the diversity of the electoral systems on the continent and the fledgling state of democracy in Africa.

Interestingly, although the ACtHPR's orders have not been fully complied with as yet, ${ }^{93}$ none of those states that were ordered to revise their national

90 Id, para 76.

91 Lohe Issa Konate, above at note 68, para 176 and Rev Christopher Mtikila, above at note 59.

92 TG Daly and M Wiebusch "The African Court on Human and Peoples' Rights: Mapping resistance against a young court" (2018) 14/2 International Journal of Law in Context 294.

93 Following the ACtHPR's judgment, Burkina Faso reported to the court that it had fully complied with the judgment by, inter alia, amending its domestic legislation on 
legislation, nor any other African country, has questioned the court's current propensity to act as a "regional constitutional court" thus far.

Whatever the reason may be for this apparent nonchalance, the ACtHPR's current approach will have a serious impact in the long run in terms of its institutional stature on the continent and in the normative development of regional constitutional law. As a continent aspiring to be peaceful, united and economically, socially and politically integrated by $2063,{ }^{94}$ the ACtHPR's role in bringing about normative integration should be something to be welcomed rather than rejected. Such integration can only be meaningful if founded on shared values, norms and standards.

\section{ACtHPR's application of sub-regional instruments}

The African Charter and the ECOWAS Democracy Protocol are similar in that they both protect the political rights of the citizens of Côte d'Ivoire and promote democratic governance in the state. As provided for in article 3(1) of the Court Protocol, the ACtHPR is free to apply a sub-regional document, as long as it is a human rights instrument ratified by the state concerned. In establishing whether a document is a human rights instrument, the ACtHPR would ordinarily refer in particular to the purposes of such a convention "expressed by enunciation of the subjective rights of individuals or groups of individuals; or by mandatory obligations on state parties for consequent enjoyment of said rights". ${ }^{95}$ Although the ACtHPR has previously applied universal instruments such as the ICCPR, this is the first time it has applied regional instruments.

\section{Independence and impartiality of national electoral bodies}

Pursuant to article 17(1) of the ACDEG, state parties to the Charter are required to establish and strengthen IEMBs responsible for the management of elections. The Court also took note and applied article 3 of the ECOWAS Democracy Protocol, which provides that: "[t]he bodies responsible for organising the elections shall be independent and / or neutral and shall have the confidence of all the political actors. Where necessary, appropriate national consultations shall be organized to determine the nature and the structure of the bodies". ${ }^{96}$ However, in the ACtHPR's view, these provisions

contd

defamation and paying the compensation ordered by the court. Tanzania's new draft constitution, adopted by the constituent assembly in 2016, is compliant with the ACtHPR's judgment but has not yet been enacted. Côte d'Ivoire publicly announced its intention to comply but is yet to amend its laws.

94 "African Union agenda 2063: A shared strategic framework for inclusive growth and sustainable development", adopted by the AU Assembly of Heads of State and Government at its 24th ordinary session, held in Addis Ababa, Ethiopia, 30-31 January 2015, available at: <https://au.int/en/agenda2063> (last accessed 20 February 2019).

95 APDH $v$ Côte d'Ivoire, above at note 36, para 57.

96 Id, paras 114-15. 
do not provide "precise indications as to the characteristics of an 'independent' and 'impartial' electoral body". ${ }^{97}$ In APDH $v$ Côte d'Ivoire, the ACtHPR determined that an electoral body "is independent where it has both administrative and financial autonomy; and it offers sufficient guarantees of its members' independence and impartiality". ${ }^{98}$

In arriving at this decision, the ACtHPR was guided by the dictates of article 27(1) of the Court Protocol, which requires it, where it has found a violation, "to make appropriate orders to remedy the violation, including the payment of fair compensation or reparation." Indeed, the court noted that "where a State becomes a Party to a human rights treaty, international law obliges it to take positive measures to give effect to the exercise of the said rights". ${ }^{99}$ The other consideration was that the orders were clearly and appropriately formulated, although this did not stop Côte d'Ivoire from requesting an interpretation of the judgment, seeking, inter alia, "more specific indications on the nomenclature of the new IEC especially with regard to its organization, background, mode of appointment of its members and distribution of the seats". 100

The existence of diverse legal jurisdictions in Africa presents the challenge of formulating or composing an "ideal best model" electoral body. However, the standards set by the ACtHPR that an independent and impartial electoral body is one that is independent in terms of finances and administration will provide a guide for state parties when they are reconstituting their electoral bodies to conform to their obligations under international and regional human rights instruments. ${ }^{101}$

\section{CONCLUSION}

The Court's judgment in APDH $v$ Côte d'Ivoire constitutes a wide and inclusive interpretation of what a "human rights instrument" is for the purposes of determining its jurisdiction pursuant to article 3 of the Court Protocol. The Court's decision entails looking into the purposes of a treaty to determine the substantive rights a convention confers, in addition to the obligations it places on states. This would mean that, after this judgment, a host of treaties, at both regional and international level, that state parties to the Court Protocol have ratified, can probably now be relied upon by applicants before the ACtHPR. Furthermore, the ACtHPR's willingness to interpret provisions guaranteeing fair elections as indirectly protecting other fundamental human rights is also of note. Consequently, it may now only be necessary to show

\footnotetext{
97 Id, para 116.

98 Id, para 118. This is also the position of the International Institute for Democracy and Electoral Assistance (IDEA) in Electoral Management Design Handbook (2010, IDEA) at 7.

99 APDH $v$ Côte d'Ivoire, id, para 61.

100 App no 003/2017, judgment of 28 September 2017: interpretation of the judgment of 18 November 2016, APDH v Côte d'Ivoire.

101 Windridge "Equality and electoral commissions", above at note 64, para 118.
} 
some indirect link between the rights in the treaty on which an applicant seeks to rely and other recognized fundamental rights in order for it to be considered a human rights treaty. This marks a positive development in the ACtHPR's jurisprudence because, as noted in this article, the greater the number of instruments to which individuals can have recourse before the ACtHPR, the more robust the system of human rights protection will be in Africa.

The Court's judgment is also significant because it consolidates its earlier jurisprudence with regard to the protection of the right of individuals to participate freely in their state's public affairs. In the consolidated cases of Tanganyika Law Society and Legal and Human Rights Centre $v$ United Republic of Tanzania and Mtikila $v$ United Republic of Tanzania, the ACtHPR highlighted the importance of safeguarding that right. ${ }^{102}$ However, the APDH $v$ Côte d'Ivoire judgment is the first concerning an electoral body. In finding that the imbalance in the numerical composition of such a body can result in a violation of international obligations, the ACtHPR has laid down an important decision that may impact the examination of similar cases in the future. ${ }^{103}$

In the final analysis, the ACtHPR ordered Côte d'Ivoire to amend Law No 2014-335 to conform it to the applicable human rights instruments. Two aspects of the judgment are of particular interest. The first relates to the direct connection the ACtHPR made between the failure to establish an independent and impartial electoral body and the right to participate freely in the conduct of public affairs. Arguably, the ACtHPR's judgment suggests that individuals also exercise this right through the fair composition of an independent and impartial electoral body, which additionally should be able to organize transparent, free and fair elections. The second aspect lies in the distinction that the ACtHPR made between institutional independence or legally formalized independence and the real independence of a body as perceived by the public. In the present instance, the applicant argued that the public's perception was that the IEC was not able to organize free, fair and transparent elections, as its unbalanced composition gave an electoral advantage to the ruling party and the government. ${ }^{104}$ The Court agreed with this argument.

In deciding that the ACDEG is a human rights instrument, the ACtHPR gave a clear indication that it will not hesitate in the future to find other instruments ratified by the relevant state as justiciable before it, so long as they contain rights that can be enjoyed by individuals. Following the judgment in APDH $v$ Côte d'Ivoire, it is now incumbent on state parties to ensure that they respect the rule of law, democratic governance and the right to equality before the law. Indeed, the case has set a standard for national electoral bodies across the continent, which will contribute to strengthening democratic governance throughout Africa.

102 Apps no 009/2011 and 011/2011, respectively, judgment of 14 June 2013, paras 107.1-119.

103 MJ Ayissi "Introductory note to APDH v Côte d'Ivoire" (November 2016) American Society of International Law 574.

104 See APDH $v$ Côte d'Ivoire, above at note 36, para 16. 